\title{
顎の変位を伴つた前茵部反対咬合の
}

\author{
オクルーザルリハビリテイション \\ 三原 益廣梅香路英俊菅尾 泰典 \\ 倪内 修平 丸山 剛郎 下総 高次
}

\section{Occlusal Rehavilitation of Anterior Cross-bite with Mandibular displacement}

Masuhiro Mihara, Hidetoshi Umekōji, Yasunori Sugao,

Shūhei Miyauchi, Takao Maruyama, Takaji Simoosa

\section{緒言}

補綴処置にあたり，ややもすると，審美的回復を含め た形態のみに重点がおかれ，機能下における補綴物の動 態, すなわち, 下頇運動との調和などの咬合に関する配 慮が忘れられがちである1).

ここに紹介するのは，上頻前歯部金属焼付ポーセレン 冠の破析を主訴として来院した患者で, 既往歴として, 下影前歯部金属焼付ポーセレン冠の数回にわたる脱離が ある. 初診時に上記主訴の他に前歯部反対咬合と，下顎 閉口運動の乱れが観察された. 上頻前歯部に見られた金 属焼付ポーセレン冠の破析を診査してみると，技工的な ポーセレン焼成操作のミスによるとは考えられないこ と，および前歯部反対咬合，下顎閉口路の乱れが観察さ れることなどから，咬合に問題があることが考えられ た. すなわち本症例でみられた前歯部反対咬合は, いわ ゆる真性のものではなく，後天性 (獲得性) のものであ り，まちがつた咬合診断による補緅処置のため，咬合の 不調和から下影閉口の乱れを生じ，さらには上頇前歯部 補緅物の破析や下顎前歯部補綴物の脱離を招いたものと 考えられる.

そこで著者らはこの後天性反対咬合の治療に目的を㯰

大阪大学歯学部歯科補緅学第 1 教室

1st Department of Prosthetic Dentistry Osaka

University, Dental School

昭和 53 年 3 月 1 日受付
いて, 䫟口腔機能系の調和をはかりつつ, フルマウスリ コンストラクションを行い, 満足すべき結果が得られた ので報告する.

\section{症例}

\section{症例の概要}

患者 : 26 歳 女性 昭和 24 年 7 月 25 日生.

主訴：上澦前歯部金属焼付ポーセレン冠の破折. 既往歴 :

（全身的）昭和 46 年 腎盎炎 現在治療.

（局所的）昭和 32 年ごろ，上下預前歯部反対咬合 に気づいたが, そのまま放置.

昭和 45 年 : $\overline{6 \mid 6}$ 技去.

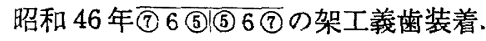
昭和 49 年: $1 \longdiv { 1 2 }$ の歯根端切除. 昭和 50 年 : $\overline{1 / 12}$ の連結金属焼付ポー セレン冠装着, その後しばしば脱離.

昭和 50 年：1112 の金属焼付ポーセレ ン冠装着.

昭和 50 年 : 1 の金属焼付ポーセレン冠 破折.

現 症 :

（全身的）健康で異常なし.

(局所的)

口腔内所見 :

初診時の口腔内所見は（図 1,2$)$ のとおりであるが， 


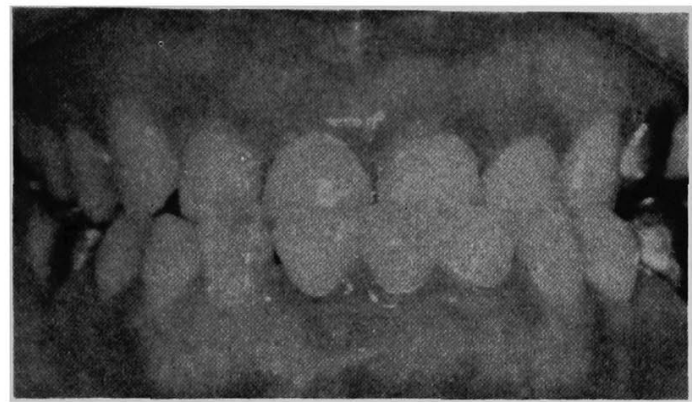

図 1 術前口腔内写真 (咬頭嵌合位)

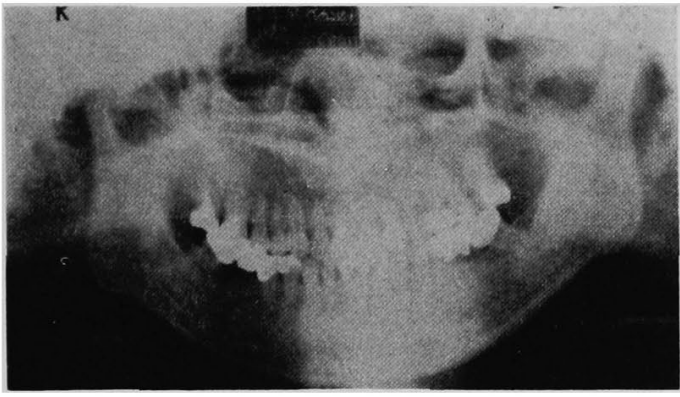

図 3 パノラマX線写真
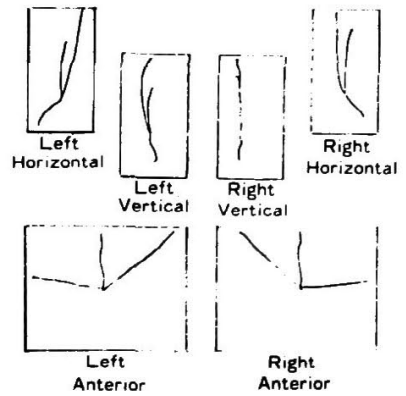

図 5 ティナーパントグラフによ る下顎運動の記録
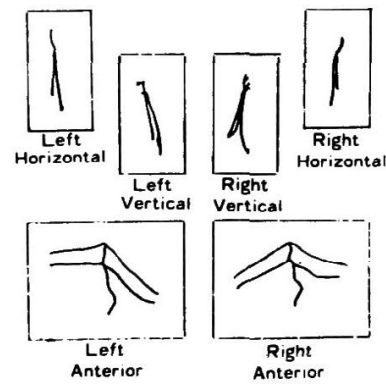

図 6 ディナーパントグラフを応 用した下矤運動の記録

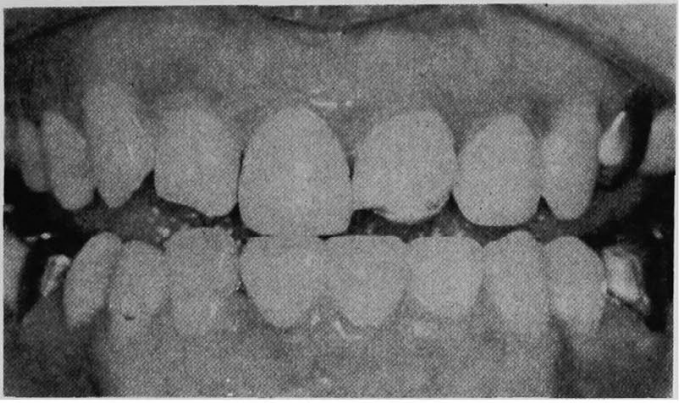

圆 2 術前口腔内写真 (下顎後退位)

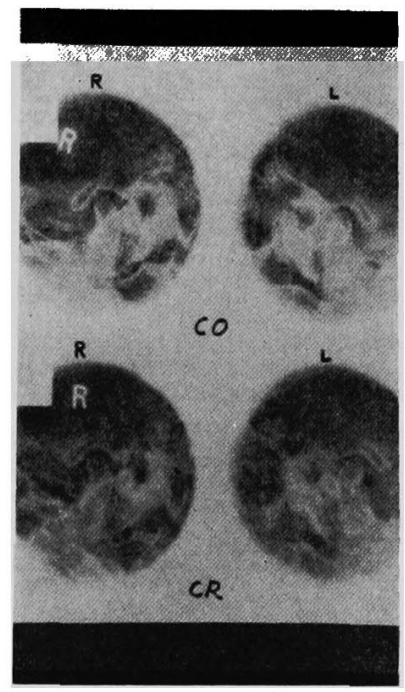

図 4 顎関節X線規格写真

（上·咬頭嵌合位, 下・磊後退位）
$1 \mid 12$ に金属焼付ポーセレン冠が装着されており，|1 の 破折および正中のずれが認められた.

下顎は $\overline{6 \mid 6}$ 欠損で $\overline{75 \mid 57}$ を支台とした固定性架工 義歯が装着されている. 歯肉状態は全体的に健康色をし ているが, 上下顎前歯部に, 出血傾向, $\overline{7 5 \longdiv { 5 7 }}$ の解緅 物辺縁に腫張が認められた。

咬頭嵌合位では, $\frac{21 \mid 123457}{2112}$ が交差咬合になつ ており，審美性に久ける。 下顎閉口時に $\frac{1}{1}$ に早期接触 がおこり，下顎は左側前上方に変位する.

パノラマX線写真所見（図 3 )

下影前歯部に歯槽骨の吸収が見られ，他の部位に比較
して，歯槽硬線も不明瞭である. 上顎前歯部および，上 下頧臼歯においては，歯槽硬線は明瞭であり，根尖病巣 も認められない.

顎関節X線規格写真による分析（図 4)

咬頭嵌合位にお゙いて左側の顆頭は，関節窩のほぼ中央 にあるが，右側の顆頭は，やや前方に位直している．下 顎後退位においては，左右側顆頭は，関節窩のほぼ中央 に位置している.

ディナーパントグラフによるロ外描記分析（図 5 )

上顎にスタイラス，下枵描記板を装着し，咬頭嵌合位 から左右側方運動および前方運動を行わせた. すべての 


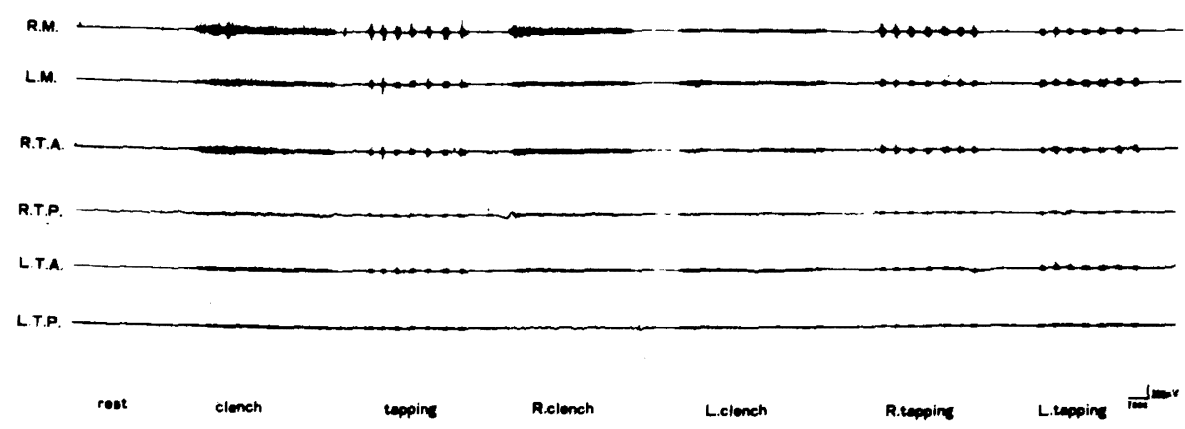

图 7 脱電図

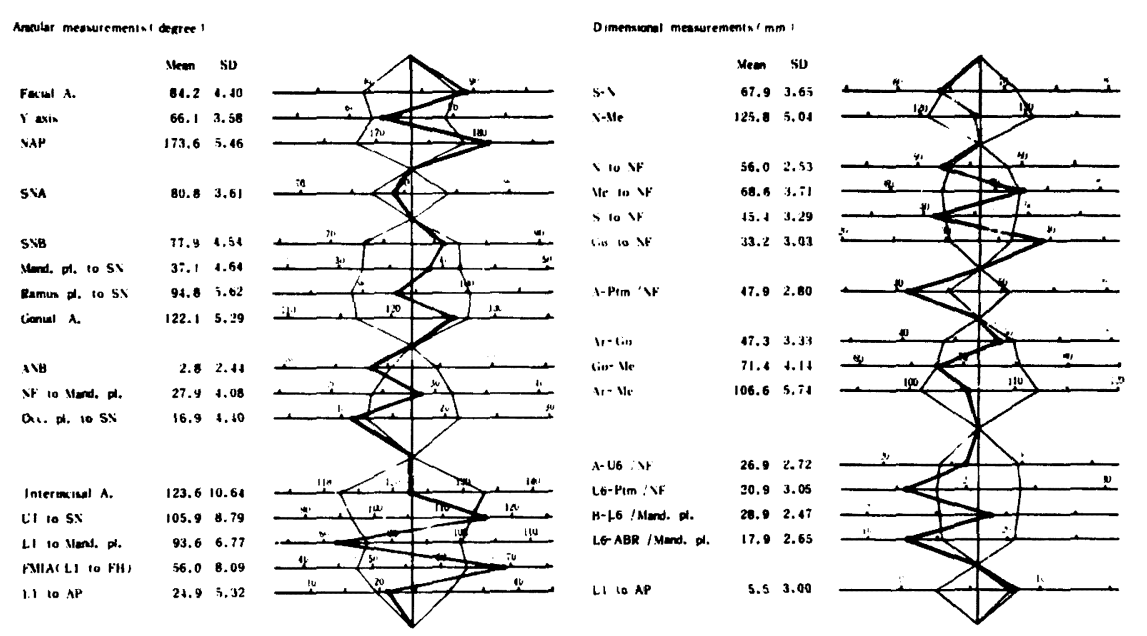

図 8 頭部X線規格写.真の分析

描記線は非常にスムーズである.

ディナーパントグラフを応用した口外描記分析（図 6)

これはディナーパントグラフを応用し，上顎に描記板 を下頡にスタイラスを装着し，歯牙接触状態での下顎後 退位から, 左右側方運動, 咬頭嵌合位から左右側方運動 および前方運動を行わせた．下顎後限位から咬頭嵌合位 への径路において, 左側前方への変位が見られ, 前方運 動径路においては限界位に達する前に右先一変位し再び 左側への変位が認められる.

筋電図による分析（図 7)

咬筇, 側頭筇前腹, 後腹の安静, かみしめ, タッピン グ，左側および右側でのかみしめ，タッピング時の左右 の筋活性，バランスを観察すると，かみしめ，タッピン グ, 左側, 右側でのかみしめ, タッピングにおいて, 右 側側頭筋後腹の筋活性が左側に比較して低い.

頭部X線規格写真による分析（図 8)

SNA，SNB，MP-SN が正常値に近い值をなし，下顎
骨の大きさが, 頭蓋骨とほぼ調和し, gonial angle も 正常者の平均値に近い值を示している.

\section{診断と処置方針}

主訴である 1 の金属焼付ポーセレン冠の破折はポー セレン内で生じており，金属焼付ポーセレン冠製作上の 失敗によるものではない，原因は外的因子，すなわち下 影が!1金属焼付ポーセレン冠に破折をおこすような咬 合を,その機能運動籁囲に含むという咬合上の問題が考 えられた. また下頢 1/12の連結金属焼付ポーセレン冠 の脱離に関しても，同様の原因が考えられた，その咬合 に関しては，患者自身が楽に前歯部切端咬合の位置に下 頻を後退させることができること．閉口径路において， 下額は左側前上方に変位しながら，咬頭嵌合位に達する こと. 頭部 X 線規格写真の分析の結果, SNA, SN B, MP-SN が正常值に近い值をなし，下顎骨の大きさが， 


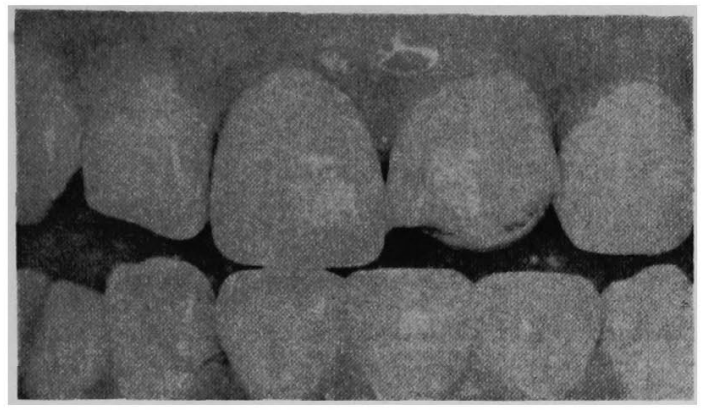

図 9 下顎 後 退 位

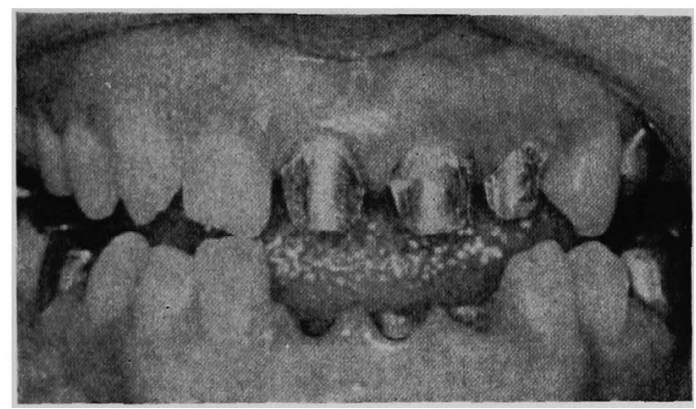

図 11 下頡後退位 $\left(\begin{array}{l}112 \\ 112\end{array}\right.$

頭蓋骨とほぼ調和し，gonial angle も正常者の平均值に 近い值を示していること．顎関節X線規格写真において 咬頭嵌合位における顆頭位は, 下䫑後退位に比較して前 方に位置していること.パントグラフの分析においても 下顎後退位から咬頭嵌合位への径路において左側前方へ の変位等が認められること. 以上の分析結果を総合する と本症例はいわゆる aquired mesio occlussion と診断 できる.

処置方針は，上下顎咬合関倸をそのままに放置して， 金属焼付ポーセレン冠のみの再製を行うことは，再度金 属燒付ポーセレン冠の破折，および，下顎前歯部金属焼 付ポーセレン冠の脱離の可能性が十分あること.また脱 離しないように正しく補緅物を装着すると，歯牙は機能 時に值接水平方向の力を受け，歯周組織疾患を惹起する 可能性や，額関節症等の顎口腔系に異常をきたす可能性 があると考えられた. そこでこの患者の場合，下頡を楽 に後退させた位置で，わずかに上颔前歯部を唇側傾斜さ せることによって，前歯部に正常な上下顎歯牙の位固関 係を与えることができ，咬合に起因すると考えられる金 属焼付ポーセレン冠の破折の危険性の減少, 審美的回 復, 顎口腔系の安静, 機能, 健康の保持ができると考え

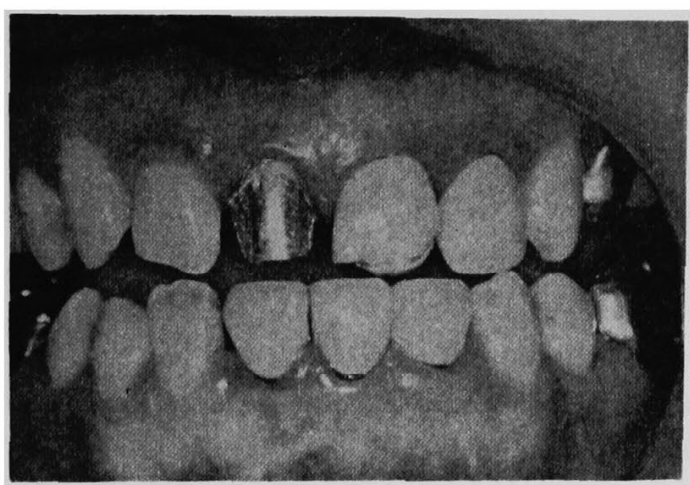

図 10 下顎後退位（1!のクラウン撤去後）

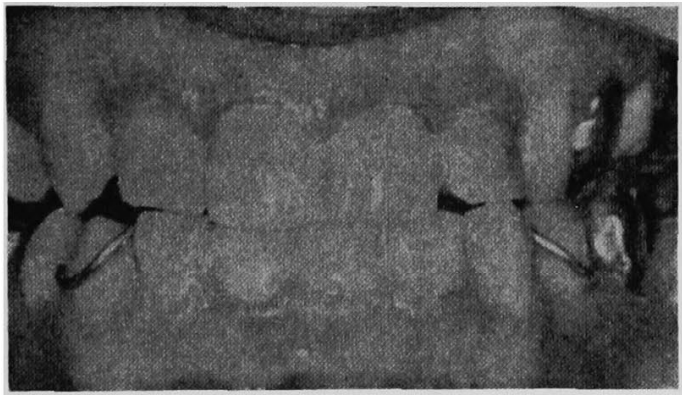

図 12 前歯部暫間補㥪物装着（正面像）

られた. 以上の考えに基ゔいて，下䫑後退位で上下額歯 牙が咬合するように補緅物の診断，設計を行つた。

\section{治療経 過}

患者自身で楽に下碩を後退させると図 9 に示すように 1 1 に接触が認められた. 次いで図 10 に示すように1|の クラウンを撤去した. その結果 $\mid \frac{2}{3} に$ 接触が認められた. さらに，11 および 12 のクラウンを撤去した結果, 図 11 に示すように $\frac{2}{2} に$ 接触が認められた. ここで, free way space, 審美性, 歯䜔等との関倸を考虑しながら咬 合調整を行つた. その結果図 12 のごとく、上下前歯部 に正しい被蓋関係が得られた，そして離開した臼歯部に は下影にスプリントを装着した. 前茵部オーパージェッ ト $1 \mathrm{~mm}$,オーパーバイト $1.5 \mathrm{~mm}$ を付与し, 下顥後退 位で 4 前菌に均等なセントリックストップを付与した （図 13）.また臼歯部スプリントで機能時に生じる咬頭干 涉の除去と下䫑後退位でのセントリックストップを確保 した (図 14).

暫閏補緅物装着 1 週間後

顎関節 X線写真撮影の結果, 両側顆頭とも関節窩の中 


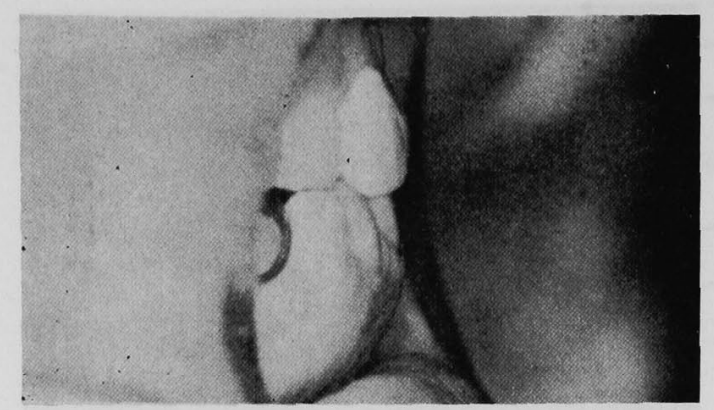

図 13 前歯部暫間補綴物装着（側面像）
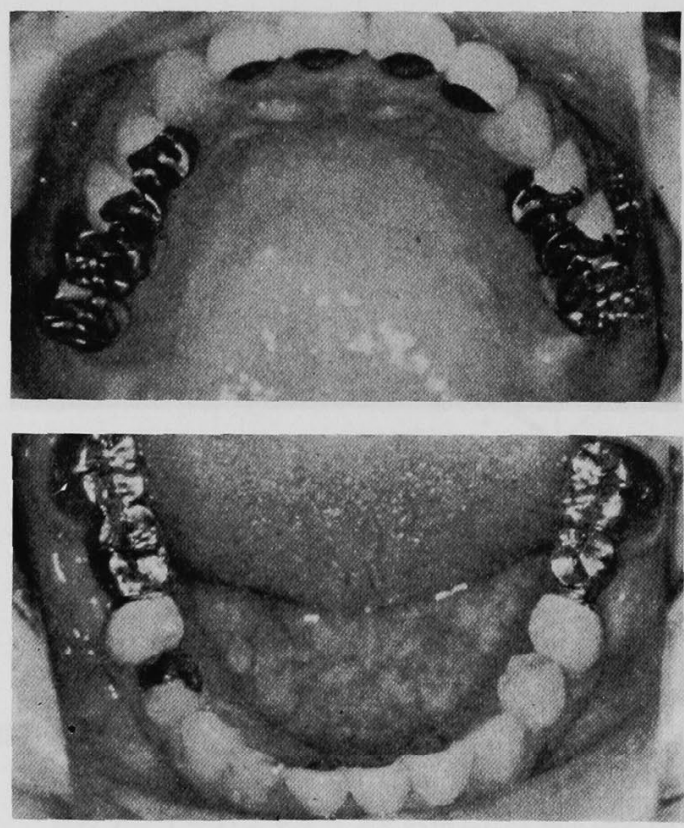

図 15 最終補䌡物装着（上·上顎，下－下顎）

央に存在することを確認した. EMG では右側のかみし め, タッピングにおいて, 側頭筋後腹のわずかな不調和 が認められた。

3 週間後

EMG で，両側および片側性かみしめ，タッピングに おいて，側頭筇後腹の不調和が認められた。

5 週間後

EMG で，やはり側頭筋後腹の不調和が認められた.

5 力月後

EMG で，ほとんど筋活性に良好なバランスが認めら れた. この間, スプリントの調整は来院ごとに行った. 最終的には, 筋活性のバランスが認められ, 咀獣筋の疲

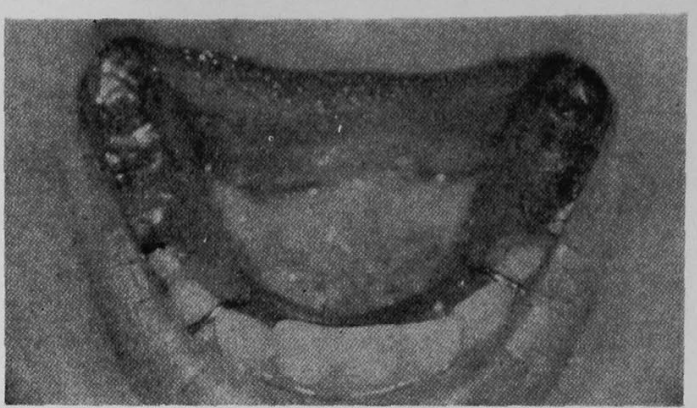

図 14 臼歯部スプリント装着

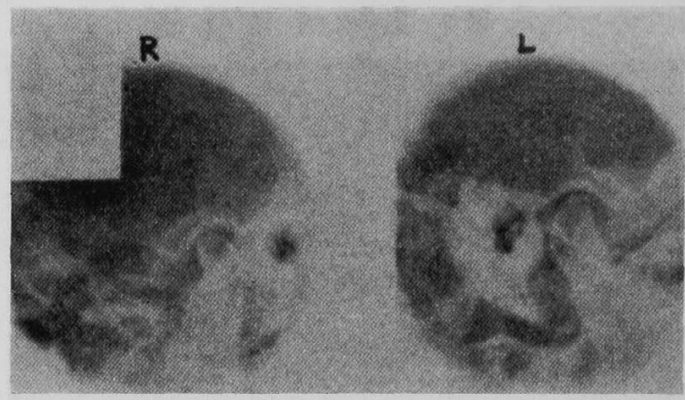

図 16 顎関節X線規格写真

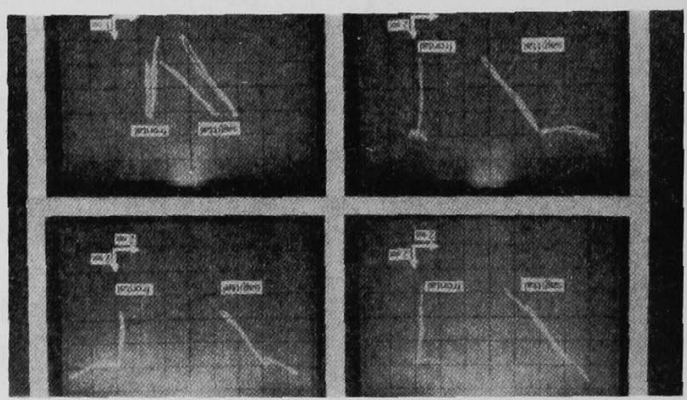

図 17 マンディブラキネジオグラフ像

労, 疼痛, 歯牙の動摇, 顎関節の雑音, 疼痛等も観察さ れず,この咬合関係で最終補緅物を装着しても，なんら 問題はないと判断した。

最終補緅物として 5422111245 に金属焼付ポーセ レン冠を, $76 \mid 6$ に全部鋳造冠を装着し, $\overline{1} 1 \overline{1} 2$ に連結 金属狫付ポーセレン冠, 可6(5)(5) 6(7)には $\overline{5 \mid 5}$ に金属焼 付ポーセレン冠を含む固定性架工義歯を装着した（図 15).

最終補緅物装着 6 力月後の予後調査

EMG でほとんど筋活性に良好なバランスが認められ た. また咬頭嵌合位の䪽関節 $\mathrm{X}$ 線規格写真においても， 両側顆頭が関節窩の中央に位置し（図 16），マンディブ 

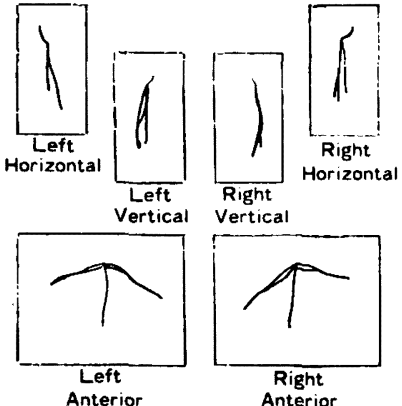

Vertical

図 16

ディナーパントグラフを応用 した下顎運動の記録

ラーキネジオグラフにおいても，前方，左右側方運動の 軌跡は安定し，異常は認められず（図 17），ディナーパ ントグラフにおいても，下䫟後退位から，咬頭嵌合位， および前方運動径路に顎の左右側への変位は認められな い（図 18）. また患者自身むいかなる頡口腔系の異常を も訴えていない.

\section{考察}

顎口腔系の機能は顎関節，上下顎歯列，および，咀緭 筋群によって営まれ，それが神経系の統合作用により機 能的に調和していることが重要であり，そのうち1つで む障害, 異常があれば鿓口腔系全体が, 不均衡な状態と なる. そのためこの系が調和した機能を営んでいるかど うか診断するためそれぞれ分析する必要があり，EMG， 顎関節 X線規格写真, 頭部 X線規格写真, パントグラフ, パノラマ, MKG を使用して診査した. その結果, 本症 例の場合, 下䫟閉口時に生しる前歯部早期接触が顎の変 位，筋の不調和，前歯部補緅物の破折，下頭前歯部歯槽 骨の吸収を惹起し，さらに審美性にも悪影響を及ぼして いると診断し，先に述べた治療を行った．以下それぞれ に関して考察を行う.

。金属焼付ポーセレン冠の破折

本症例で観察された破折面には，わずかに金属面の露 出が認められたのみで，大部分のポーセレンの残存を認 めた. このことは外的因子つまり反対咬合による下頡前 歯の当該歯切端に対する過度の咬合力が作用したことが 推察される. この患者の術前の下䫟開閉運動に見られた ように，閉口路においてまず前歯部切端のみに早期接触 がみられ，次の段階で下狉前歯が上䫑前歯唇面を滑走し がら終末位で反対咬合となり四歯部の接触が認められ る. すなわち最初の切端早期接触の際，前歯部が負担荷

重となる. 切端部は，金属の支持がなくポーセレン単独 であるため荷重に対して抗しきれず破折したものであろ う.したがつて本症例の場合，抗破折の対策として，切 端部早期接触を除去することが必要であり，そのために は，上下前歯の位置関係を正常咬合に回復すること．あ るいは逆に過度の反対咬合を与えることが考えられる。

acquired mesio occlusion について :

acquired mesio occlusion $は$, pseudomesio-occlusion, pseudoprognathism, pseudo class III malocclusion, false mesio-occlusion, false prognathism, false class III mesio occlusion, functional mesio-occlusion, anterior cross bite, apparent prognathism, compulsive prognathism, postural class III などどと呼ばれ ている. 本症例の診断については, その根拠等は, すで に記載したが, acquired mesio occlusion と真性の下 顎前突の鑑別方法に関して Moyers ${ }^{2)}$, Graber $^{3)}$, Ross $^{4)}$ らの報告を参考にしてそのポイントを具体的に述べる.

acquired mesio occlusion

（1）患者は無理なく上下顎 前歯を edge-to edge relation でかみ合わせる ことができる.

（2）下顎閉口路において上 下顎前歯部の干涉によ り，下顎は前方変位する か，もしくは上下顎歯牙 接触直前に歯牙干渉なし に前方変位する.

(3) 閉口終末位付近で vertical dimension が減少 するような運動が見られ る.

（4）下顎骨の大きさが頭蓋 骨と調和している.

(5) 上頡の前部において成 長が悪く, 後部は形態大 きさにおいて正常であ る.

（6）下䫟枝と下狉体のなす 角が直角か直角に近い鈍 角になつている。

（7）上顎臼歯の煩側咬頭は true mesio occlusion

(1) 上下頡前歯が edge-toedge relation になるま で下顎を後退できない.

（2）下顎閉口路においてス ムーズな曲線を描く。

（3）そのような連動が見ら れない。

（4）下顎骨は頭蓋骨に比較 して長く広い。

（5）上澦全体が発育が悪 W.

（6）下顎枝と下顎体のなす 角が大きな鈍角を示し， 場合によつて直線に近い ものもある.

（7）上顎臼歯の煩側咬頭は 


\section{下顎臼歯の煩側咬頭の㛲} 側にあるか, cusp-tocusp の関係にある.

（8）上下䫛前歯部被蓋は深 $<$ free way space $も 大$ である。

\section{下顎臼歯の煩側咬頭の舌} 側にあるか, cusp-tocusp の関係にある.

(8) 上下䫛前歯部被蓋は浅 w.

\section{咬頭嵌合位の決定について}

本症例において, 頭部 X線規格写真分析の結果, 上下 顎骨の大きさが調和していることがわかり，下顎が咬頭 嵌合位に達する直前に左側前方に変位するため $\frac{21 \mid 12}{21 \mid 12}$

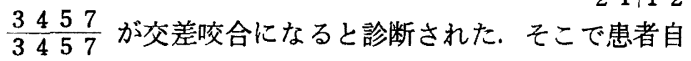
身に下顎後退位をとらせると上下䇗の位置は調和のとれ た関係になり，この位置を咬頭嵌合位にすることが，上 下額歯列の関係, 審美性の点から, 望ましいという結論 にいたつた.

しかしここで垂直的頡関係すなわち咬合高径をどのよ うにするかという点が問題となる. 垂直的すなわち咬合 高径の決定に関して狉機能時に筋の働きが無理なく発 揮されなければならない前提がある. 末次ら5)は無歯額 者に関して，咬合高径の決定の基準とされている下䫑安 静位およびその他 7 䫑位の相対的位置関係を研究し, そ れは上下的, 前後的にある程度の変動があることを明ら かにしいる. 現在下顎安静位からの咬合高径の決定に関 しては, 下顎安静位が Thompson ${ }^{6}$ のいうように生涯一 定不変のものでなく同一個人においても測定者, 顎, 咬 合の変位とともに変動することが明らかになつており, 安静位から咬合高径を決めることは矢敗を招く結果とな る. しかし臨床においては咬合高径をある程度変化させ 得ることも明確であり, その挙上範卧については筋緊㖘 から考え free way space がある程度目安になつている ことは否定できない. また Maccollum ${ }^{7)}$, Dawson $^{8)}$ の いう咬合高径を変化させることによつて生じるトラブル を避けるには天然歯を有する患者においては来院時の咬 合高径をすべきでないという意見もあり，先に述べた事 実と考えあわせ著者らは処置にあたり，咬合高径の増加 は free way space の範眀にとどめるよう試みた.

水平的には，下䪽後退位で咬頭剻合させることによる 䪽関節および筋にあたえる影響を考えなければならな い9． 本症例においては下顎を後退させることによつて 右側顆頭は少し後方へ変位する. 顎関節機能が正常であ る者の顆頭位の研究において Weinberg $5^{10)}$ は, 正常者

では最大咬頭嵌合位の両側顆頭は関節窩のほぼ中央にあ り左右対称的であると述べており, Posselt も左右の関 節窝内での顆頭の位直が対称的でない者は䫟関節，笳， 咬合になんらかの異常があるものと判定している．また 解剖学的に関節の構造は増令化とともに一定の変化を示 し，それが歯牙の哥失すなわち咬合の岥失に伴ら機能の 変化が顎関節構造の変化を惹起したものを推測され頻関 節が咬合と密接な関係にあるといえる.この患者の場合 年齢的にも若く，順応性も富むと考えられ，また下額後 退位の䫑関節 X線規格写真より左右両側顆頭の位置関係 はほぼ対称で関節窩の中央にあり，この位置で筋を含め て安定すれば理想的であると考える.

今一つ問題になるのはこの下䫑後退位は㭧者自身が無 理なく下顎を後退させた位置である. そのため外力を加

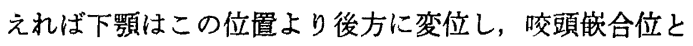
中心位との間に一定のずれが生じる，咬頭嵌合位と中心 位の関倸に関しては, 種々の見解が説えられている. Posselt, Dawson, Kydd, Sicher らは全く別個のものと 考え, Graber, Macollum, Stuart らは同一のものであ ると考え，また Schyler はその 2 つの間に 1 つの領城を 設けることを提唱している. しかし正常咬合をもつ成人 のほとんどは中心位は咬頭嵌合位の後方にある事実と嚥 下時その他の特殊な咬合時, 下䫑が咬頭嵌合位より後方 に位置し, その場での異常な早期接触が顎機能に悪影響 をあたえることも事実であり，それらを考え合わせると 中心位と咬頭嵌合位が調和のとれた関係になければなら ないと判断できる. 本症例の場合, 治療後の中心位と咬 頭嵌合位の間には MKGの測定により前後的に $0.5 \mathrm{~mm}$, 上下的には $0.1 \mathrm{~mm}$, 左右的には $0.2 \mathrm{~mm}$ のずれが認め られるが, 中心位から咬頭嵌合位への滑走に関しては, 顎関節, 筋, 歯牙, 歯周組織に異常を起こさないように 咬合調整を行つた.

\section{スプリントについて}

使用目的として Posselt ${ }^{11)}$ は，(1)歯ぎしりおよびその 影響の防止，(2)顆頭と関節裔との関係の修正，(3)筋けい れん，顎関痛の除去，(4)咬頭干涉の防止，(5)診断用，など を記している. 分類に関しては, Krogh-poulsen ${ }^{12)}$ は, (A) relaxation splint, (B) stabilization splint, (C) resilient splint, (D) pivoting splint, (E) bite splint に分類している. 本症例においては, 顆頭と関節窝の関 係の修正, 咬頭干涉の防止, 前歯部反対咬合の改善に伴 う曰歯部離開の補償を目的として装着した. スプリント 
は使用目的により，その形態を異にしており，本症例に おいては水平的に下影を変位させ，その位置での安定を 計ることが第 1 の目的であるため，スプリントの咬合面 に上顎臼歯部の咬頭が嵌合する窩を設けることで，閉口

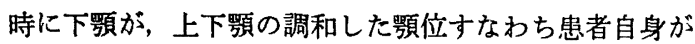
楽に取りうる下頡後退位に誘導している．またその位固 から自由な前方，側方運動が行われ，平衡側の咬頭干涉 を避けるように調整し，歯列弓の関係より下頻に装着し た.

\section{EMG について}

滪運動は咀嚼筋群の活動によつてなされているため, 咀嚼系の機能を生理的かつ客観的に診查する目的で EMG 使用した.

1. 術 前

咬筋，左右側頭筋前腹はいずれも調和がとれており， この咬合状態で順応していると思われる. 左側側頭管後 腹に関しては機能時, 常に右側に比較して強い笳活性を 示したのは，下頡が閉口終末位近くで左側前方へ変位す る結果生じる筋群への stressのためと思われる.

2. 術 中

咬笳, 左右側頭筋前腹は術前より作働筋, 非作働笳の 関係が明確であるが，側頭筋後腹では術前とは逆に右側 側頭筋後腹が安静時, 常に左側に比較して強い筋活性を 示した．それは下䫟を右側後方へ変位させた状態で咬頭 嵌合させているため，その stressが筋に加わつたものと 思われる.

3. 術後

安静時, 機能とも咬筋, 左右側頭筋前後腹すべてが調 和しており，笳は新しい咬合関係に順応したものと判断 できる.

\section{おわりに}

今日まで顎位を水平的に変化させることにより上下顎 関係を改善させた症例報告は数少なく，またそのほとん どが理論的に裏うけされないものである，本症例におい
ては, パノラマX線写真, デンタルX線写真, 枵関節 $\mathrm{X}$ 線規格写真, 頭部 $X$ 線規格写真, ディナーパントグラフ, EMG, MKGを用い, 治療経過，予後を通じて精査を行 いつつ上下䇗歯牙，咀嚼筋，䪽関節をできるだけ理想に 近い状態に構成することにより，審美的に改善されまた 将来おこる顎口腔系の異常も防止できたと確信され，ま た患者自身も満足している. 今後も予後観察を続けて行 くつもりであり，機会を得て報告したい.

\section{文献}

1）小泉 猛：下顎位の誘遒をともなったオ一ラルリハビ リテーンョンの一症例, 科医学, 1977.

2) Moyers, R.E. : Handbook of Orthodontics. 3rd ed, year Book Medical Publishers, chicago, 1973.

3) Graber, T.M. : Orthodontics, principles and practice, W.B Saunders, Philadelphia London, 1972.

4) Ross, I.E. : Acquired mesio-occlusion in adults: Treatment without oppliances, J.P.D, 1977. 38, september.

5) 末次恒夫：マルチフラッンム装置による無粎顎の前後, 開閉運動ならびに下䝷位.の研究，補緅誌，1961.

6) Thompson, J.R. : The rest position of the mandible and its significance to dental science J.A.DA, 33, 1946.

7) Maccollum, B.B. \& sturt, C.E. : A research report, Scientific Press South Pasadena, 1955.

8) Pawson, P.E. : Evaluation, Diagnosis, and treatment of Occlusal Problems, 1974.

9)坟本正湖：補緅学領域にお汁る下䫛の垂直的ならびに 水平的变化に関寸る㘯電四学的研究，九州歯会誌，23, 1969.

10) Weinberg, L.A. : Correlation of temporomandibular dysfunction with radiograpfic findings J.P.D, 1972.

11) Posselt, U. : Physiology of Occlussion and Rehabilitation A. R. Mowbray Co, Oxford, 1962.

12) Krough-Poulsen: Facial Pain and Mandibular Disfunction Philadelphia, W. B. Saunders, Co, 1969. 